\title{
Modal Intelektual dan Pengungkapan Tanggung Jawab Sosial
}

\author{
Ni Putu Krisna Dewi ${ }^{1}$ \\ Fakultas Ekonomi dan Bisnis \\ Universitas Udayana, Indonesia
}

\author{
Ni Made Dwi Ratnadi ${ }^{2}$ \\ Fakultas Ekonom dan Bisnis \\ Universitas Udayana, Indonesia
}

\begin{abstract}
Surel : tuina0911@gmail.com
ABSTRAK

Pengujian secara empiris pengaruh antar modal intelektual pada pengungkapan tanggung jawab sosial merupakan tujuan dari penelitian ini. Perseroan yang tergolong dalam daftar LQ45 Bursa Efek Indonesia periode 2015-2017 digunakan sebagai sampel pada studi yang dilakukan ini, dan metode purpose sampling digunakan untuk mengumpulkan sampel. Teknik analisis regresi berganda digunakan melalui SPSS guna menganalisa data. Dari studi yang telah dilakukan disimpulkan bahwa human capital mempengaruhi secara positif atas pengungkapan tanggung jawab sosial, pada saat yang sama, structure capital maupun customer capital sama sekali tidak mempunyai dampak apapun atas pengungkapan tanggung jawab sosial. Hasil studi yang telah dilakukan ini sejalan dengan teori resource-based, teori legitimasi, dan resource depedency theory. Teori-teori ini percaya bahwa setiap perusahaan memiliki sumber daya berbeda-beda dan unik, yang dapat menambah keunggulan kompetitif yang berkelanjutan untuk kelangsungan hidup perusahaan, tetapi perusahaan sebagai organisasi bergantung pada kekuatan untuk menyediakan sumber daya dan menggunakannya dalam operasional.
\end{abstract}

Kata Kunci: Modal Intelektual; Pengungkapan Tanggung Jawab Sosial.

\section{Intellectual Capital and Social Responsibility Disclosure}

\section{ABSTRACT}

Empirical testing of the correlation of intellectual capital and disclosure of social responsibility with, structural capital, customer capital, human capital is the purpose of this study. Companies that are included in the LQ45 list of the Indonesia Stock Exchange for the 2015-2017 period are used as samples in this study, and the purpose sampling method is used to collect samples. Multiple regression analysis technique is used through SPSS to analyze a data. Based on the previous study, it is concluded that human capital positively affects the disclosure of social responsibility, at the same time, neither structure_capital nor customer capital has any impact on the disclosure of social responsibility. The results of this study are in line with resource-based theory, legitimacy theory, and resource dependency theory. These theories believe that every company has different and unique resources, which can add a sustainable competitive advantage to the survival of the company, but companies as organizations rely on Strengths to provide resources and use them in their operations.

Keywords: Intellectual Capital; Disclosure of Social Responsibility.

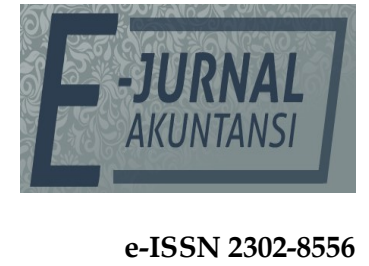

Vol. 31 No. 8

Denpasar, Agustus 2021 Hal. 1960-1972

DOI:

10.24843/EJA.2021.v31.i08.p07

PENGUTIPAN:

Dewi, N.P.K., \& Ratnadi, N.M.D. (2021).

Modal Intelektual dan Pengungkapan Tanggung Jawab Sosial. E-Jurnal Akuntansi, 31(8), 1960-1972

RIWAYAT ARTIKEL:

Artikel Masuk:

7 Januari 2020

Artikel Diterima:

3 Juli 2021

Artikel dapat diakses : https://ojs.unud.ac.id/index.php/Akuntansi/index 


\section{PENDAHULUAN}

Di masa kini, social responbility sudah bukan bagian dalam responbilitas tunggal perusahaan (single bottom line), artinya tanggung jawab perusahaan hanya bergantung pada proyeksi nilai perusahaan sebagai laporan keuangan perusahaan. Namun kini perusahaan dituntut tanggung jawab sosial yang lebih luas dengan konsep triple button lines sebagai pedoman dalam memenuhi tanggung jawab sosialnya. Konsep triple buttom lines menuntut perusahaan untuk bertanggung jawab tidak hanya kepada nilai perusahaan atau para investor (shareholder) namun juga dituntut untuk bertanggung jawab terhadap pemangku kepentingan lainnya (stakeholder) dan masyarakat sekitar. Penerapan tanggung jawab sosial ini tidak lagi dinilai sebagai sebuah biaya, tetapi sebagai bentuk investasi, karena pengeluaran atas penerapan tanggung jawab tersebut nantinya berdampak positif bagi nama baik perusahaan yang kemudian secara tidak langsung dapat menarik para investor.

Banyaknya kasus kerusakan lingkungan yang terjadi akibat aktivitas perusahaan, menjadikan permasalahan terkait tanggung jawab sosial mendapat perhatian khusus. Indonesia Social Responsibility menyakan bahwa aktivitas konsumen yang dilakukan oleh para pelaku usaha berpotensi menimbulkan kerusakan lingkungan, seperti pencemaran lingkungan yang bersumber dari pembuangan limbah pabrik ke sungai dan pemberdayaan masyarakat suku di wilayah pertambangan oleh PT Freeport Indonesia (PTFI) di Papua, ekspansi perkebunan sawit oleh Indofood dan PepsiCo yang mengakibatkan pengerusakan hutan hujan dan terjadi pelanggaran HAM, Lapindo Brantas yang menyebabkan kasus banjir lumpur lapindo di Jawa Timur, masalah terkait air di Sumatera Selatan akibat pembuangan limbah industri ke sungai secara terus menerus, dan rusaknya daerah resapan air. Penanaman kelapa sawit berskala besar, Penambangan Batubara, dan Hutan sebagai pengembangan Tanaman Industri (HTI), menyebabkan masyarakat memiliki pandangan negatif terhadap kegiatan badan usaha komersial.

Banyaknya kasus kerusakan lingkungan yang diakibatkan oleh perusahaan menjadi perhatian pemerintah. Hal ini perlu bagi pemerintah untuk menerbitkan Undang-Undang yang mengatur tentang Perseroan Terbatas. Undang-undang tersebut diberi nama UU No. 40 tahun 2017. Undang-undang tersebut menggariskan setiap perusahaan yang terkait dengan sumber daya alam wajib memenuhi tanggung jawab sosialnya kepada lingkungan, bukan hanya bertanggung jawab pada pemegang saham maupun pemangku kepentingannya. Untuk mengatur hal ini, pemerintah mengeluarkan Peraturan Pemerintah No. 12, No. 47, mengenai batasan social responbility serta lingkungan sekitar perseroan. Undang-Undang Nomor 25 Tahun 2007 tentang Penanaman Modal, yang diterbitkan sebagai pelengkap. Perundangan tersebut berpartisipasi dalam pemenuhan tanggung jawab sosial perusahaan yang memuat hal-hal yang menjadi kewajiban investor untuk melaksanakan tanggung jawab sosial perusahaan, yang mengatur bahwa setiap penanam modal berkewajiban melaksanakan tanggung jawab sosial perusahaan.

Pembangunan ekonomi dan peningkatan kualitas hidup dan kualitas lingkungan menjadi salah satu alasan untuk menunjukan peran perusahan dalam 
memenuhi tanggung jawab sosial ini. Hal tersebut tidak hanya berdampak oleh perusahaan, tapi juga memiliki dampak untuk masyarakat sekitarnya. Perusahaan yang hanya bertumpu pada aset berwujud, maka perusahaan tersebut tidak akan mampu menghadapi kerasnya persaingan pasar. Oleh karena itu, perusahaan harus dapat menggunakan aset tidak berwujudnya secara optimal. Penelitian ini menggunakan metode modal intelektual dalam mengevaluasi dan menimbang aset yang tidak berwujud. Modal intelektual atau Intellectual Capital (IC) yang lebih dikenal dalam dunia bisnis merupakan aset tidak berwujud. Keunggulan kompetitif dan kontinyuitas bagi perusahaan sangat berharga, karena sulit untuk ditiru, dan dapat menggantikan hal-hal lain pada masa mendatang.

Modal manusiawi atau Human Capital (HC), modal manfaat atau Capital Employed (CE) dan modal struktural atau Structural Capital (SC) merupakan tiga elemen dari Intelectual capital (Bontis \& Richardson 2000). Human Capital diwakili oleh pengetahuan yang dimiliki oleh karyawan, dan Capital Employed adalah pengetahuan yang melekat pada saluran pemasaran dan hubungan pelanggan. Structural Capital adalah kemampuan perusahaan untuk menyelesaikan kegiatan usahanya. Struktur yang dimiliki perusahaan dapat mendukung aktivitas karyawan untuk mencapai kinerja intelektual yang maksimal. Di Indonesia, pengungkapan tentang intellectual capital di atur dalam Pernyataan Standar Akuntansi Keuangan (PSAK) No.19 mengenai aset tak berwujud. Meskipun agak samar penjelasan modal intelektual dalam PSAK, PSAK No. 19 dianggap menjadi pengawasan aset tidak berwujud dalam aset tidak terukur, tidak memiliki bentuk fisik, dan dapat diidentifikasikan kepemilikannya. Hal ini dapat digunakan sebagai sarana produksi atau penyampaian barang dan jasa hasil produksi, yang disewakan kepada pihak lain bahkan juga bila digunakan dalam tujuan pengelolaan (Ikatan Akuntan Indonesia (IAI), 2009). Musibah \& Sulaiman (2015) menerangkan bahwa tanggung jawab sosial dapat diklasifikasikan sebagai aset tidak berwujud karena keduanya dapat saling mempengaruhi sehingga berdampak pada nilai perusahaan.

Penelitian tentang dampak modal intelektual terhadap tanggung jawab sosial telah banyak dilakukan, namun menghasilkan gambaran yang berbeda pada setiap penelitian. Razaindrambinina \& Kariodimejo (2011) menunjukkan ketiadaan hubungan yang signifikan antara modal intelektual yang dimiliki suatu perusahaan atas pengungkapan tanggung jawab sosial. Tetapi, anggapan ini secara langsung dibantah oleh Musibah \& Sulaiman (2015), yang mempelajari hubungan antara modal intelektual dan tanggung jawab sosial bank syariah di negara-negara terburuk. Penelitian ini menunjukkan bahwa CE memiliki dampak yang positif pada social responbility (tanggung jawab sosial), sedangkan HC mempunyai dampak yang negatif terhadap social responbility (tanggung jawab sosial), dan SC tidak berdampak besar pada social responbility. Bahkan hasil yang didapat pun juga berbeda terhadap studi yang telah dilakukan (Parinduri \& Halim (2019). Studi tersebuat menunjukkan bahwa HC dan SC tidak berdampak pada tanggung jawab sosial. 
Semua hasil penelitian yang tersebut diatas digunakan peneliti sebagai dasar penelitian dengan pengembangan yang perlu ditambahkan. Penelitian ini mengambil sampel tempat di Indonesia, dan objek penelitiannya adalah perusahaan yang indeksnya LQ45 pada Bursa Efek Indonesia periode 2015-2017. Pemilihan objek studi tersebut sudah melaui beberapa pertimbangan bahwa perusahaan yang tercatat pada daftar LQ45 berisi oleh berbagai industri dan merupakan perusahaan dengan tingkat permodalan yang paling signifikan, sehingga dianggap mewakili pertumbuhan ekonomi Indonesia secara keseluruhan. Penelitian ini secara empiris akan melakukan pembuktian mengenai relasi antara pengungkapan tanggung jawab sosial (social responbility) perusahaan dan human capital, capital employed, dan structural capital untuk perusahaan berindeks LQ45 di Bursa Efek Indonesia periode 2015-2017.

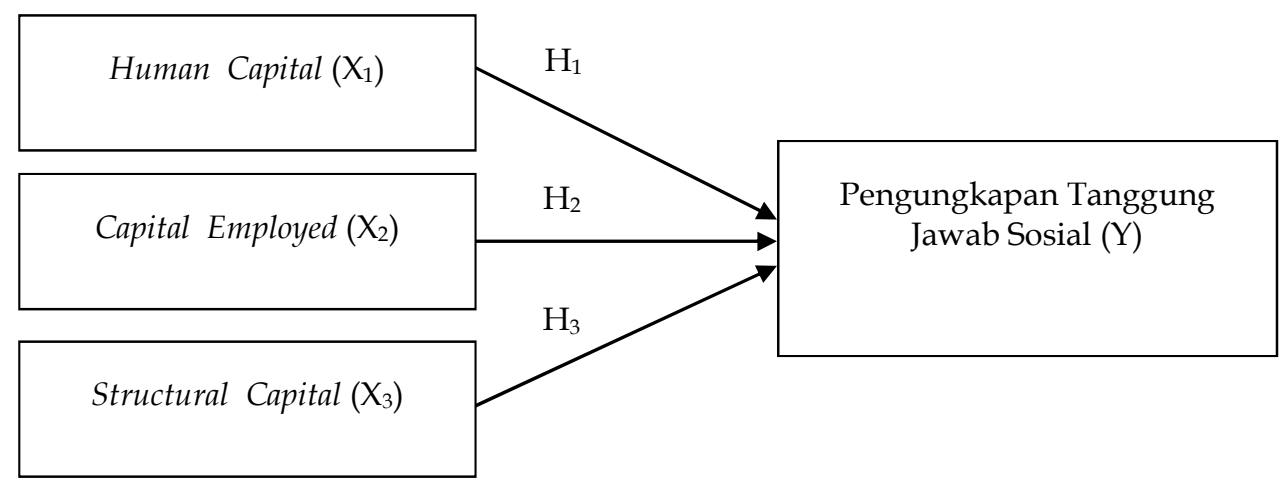

Sumber: Data Penelitian, 2019

Gambar 1. Rangka Koseptual Studi

Ketika keuntungan perusahaan dipengaruhi oleh inovasi dan pengetahuan yang intensif, modal intelektual dipercaya dapat meningkatkan keuntungan perusahaan (Edvinsson \& Malone, 1997). Teori berbasis sumber daya menunjukkan bahwa pencapaian standar modal intelektual merupakan kekuatan unik yang dapat menghasilkan nilai tambah terhadap perusahaan, apabila mereka memiliki kredibilitas dalam menciptakan keunggulan bersaing bagi perusahaan, sehingga. Di saat perusahaan mampu memanfaatkan sumber daya dengan semaksimal mungkin, perusahaan akan dapat memperoleh nilai tambah dengan menciptakan karakteristik perusahaan, seperti keunggulan bersaing, sehingga perusahaan akan memperoleh nilai berupa peningkatan kinerja perusahaan. Peningkatan kinerja perusahaan akan mempengaruhi nilai perusahaan dan bermanfaat bagi masyarakat, hingga meningkatkan harga saham dan profitabilitas hingga mampu memenuhi tanggung jawab sosial perusahaan dengan cepat. Perusahaan yang berkeuntungan bagus harus mampu menunaikan tanggung jawab sosial perusahaan dengan lebih baik serta menampilkannya secara transparan, jika tidak publik mengharapkan perusahaan bertanggung jawab kepada manajemen, investor, dan masyarakat luas. Hipotesis pertama yang dapat disimpulkan dari penelitian ini sebagai berikut.

$\mathrm{H}_{1}$ : Human capital berperan positif pada pengungkapan tanggung jawab sosial.

Peran sumber daya dalam aktivitas keuangan perusahaan dan kinerja keuangan juga dipertimbangkan dalam modal intelektual. Modal intelektual 
dapat digunakan sebagai indikator untuk memberikan dampak positif pada tanggung jawab sosial, sehingga setiap elemen modal intelektual akan berdampak pada tanggung jawab sosial (Razaindrambinina \& Kariodimejo, 2011).

Teori berbasis Sumber daya atau Resource-based theory meyakini, sumber daya perusahaan memilki sifat yang berbeda dan ciri khasnya tersendiri, yang dapat menambah keunggulan kompetitif yang berkelanjutan bagi kelangsungan hidup perusahaan. Modal intelektual perusahaan adalah sumber daya yang dipertimbangkan perusahaan untuk mewujudkan keunggulan tersebut. Dalam Musibah \& Sulaiman (2015) disebutkan bahwa modal intelektual bengaruh berpengaruh pada tanggung jawab social. Penemuan dampak ini membuat masyarakat percaya bahwa unsur modal intelektual berupa human capital berdampak positif terhadap tanggung jawab sosial.

Resource-based theory ini menjelaskan bahwa keberadaan modal intelektual merupakan faktor pertimbangan dalam menentukan tanggung jawab sosial sebuah perusahaan. Jika kemampuan perusahaan dalam mecapai keunggulan tinggi maka modal intelektual perusahaan yang diperlukan pun tinggi, hal tersebut telah diatur dalam tanggung jawab sosial dan lingkungan Musibah \& Sulaiman (2015)Unsur-unsur modal intelektual dalam bentuk penggunaan modal capital employed (CE) diyakini memiliki dampak positif pada tanggung jawab perusahaan. Hipotesis kedua dari penelitian ini sebagai berikut.

$\mathrm{H}_{2}$ : Capital Employed mempunyai dampak yang positif terhadap pengungkapan tanggung jawab sosial.

Hal ini memeiliki dampak bagi sumber dayanya, terutama modal intelektual, merupakan aset perusahaan, dan perlu mendapat perhatian khusus ketika memperoleh keunggulan kompetitif yang berkelanjutan. Menurut teori berbasis sumber daya, sumber daya suatu perusahaan sangat berbeda dengan perusahaan lainnya. Sehingga, keunggulan bersaing setiap perusahaan tentu akan berbeda-beda. Salah satu keunggulan kompetitif yang dimiliki sebuah perusahaan merupakan keunggulan kompetitif perusahaan itu sendiri dalam tanggung jawab sosial dan lingkungan perusahaan. Hasil penelitian Musibah \& Sulaiman (2015) menghasilkan temuan yang terkait pengaruh antara modal intelektual dan tanggung jawab sosial. Oleh karena itu, Structured Capital (SC) dinilai berdampak positif terhadap tanggung jawab sosial. Hipotesis ketiga dari penelitian ini sebagai berikut.

$\mathrm{H}_{3}$ : Structural capital mempunyai dampak yang_positif terhadap pengungkapan tanggung jawab sosial.

\section{METODE PENELITIAN}

Dalam pemilihan metode penelitian, peneliti menggunakan metode kuantitatif karena semua analisa berhubungan dengan angka. Dalam menganalisa datanya menggunakan korelasi kuantitatif yang menghitung hubungan antar variabelvariabel terkait. Variabel-variabel tersebut adalah human capital, used capital, structured capital dan corporate social responsibility yang akan dianalisa secara empiris hubunganya dengan protected intellectual capital. Subjek yang diteliti merupakan perusahaan yang terdaftar dalam indeks LQ45 Bursa Rfek Indonesia tahun 2015-2017. 
Pengambilan sampel menggunakan Teknik sampel yang disengaja. Hal ini berarti sample yang memenuhi kriteria yang akan dianalisa oleh peneliti. Kriteria tersebut dapat dilihat dari perusahaan terdaftar di Indeks LQ45 Bursa Efek Indonesia selama tiga tahun berturut-turut, dan menggunakan data terbaru yang diperoleh pada periode 2015-2017 guna mendukung penelitian. Batas waktu untu pelaporan sampai tanggal 31 Desember dan mata uang pelaporan adalah rupiah. Lapooran laba rugi komperhensif dengan angka laba yang positif merupakan sebuah indikasi bahwa perusahaan telah memanfatkan sepenuhnya modal intelektual untuk menghasilkan laba.

Penelitian ini menggunakan teknik dokumentasi dan kepustakaan sebagai teknik pengumpulan data. Setelah data terkempul, peneliti menganalisa melalui SPSS dengan menggunakan analisis linier berganda. Sebelum itu, peneliti akan menganalisa atau menghitung uji hipotesis klasikal dan uji kelayakan. Model regresi linier berganda dirumuskan sebagai berikut.

$\hat{Y}=\alpha+\beta_{1} X_{1}+\beta_{2} X_{2}+\beta_{3} X_{3}+\beta_{4} X_{4}+\varepsilon$

\section{HASIL DAN PEMBAHASAN}

Berdasarkan pengambilan populasi, terdapat 35 perusahaan yang menjadi populasi dengan indeks LQ45 di Bursa Efek Indonesia dari tahun 2015 sampai dengan tahun 2017. Akan tetapi setelah menerapkan teknik pengambilan sampel tanpa probabilitas, sampel tersebut hanya terdapat 24 perusahaan yang memenuhi standar kategori. Tabel 1, menampilkan proses seleksi sampel dari populasi yang ada.

\section{Tabel 1. Proses Seleksi Sampel}

\begin{tabular}{|c|c|c|}
\hline No & Keterangan & Jumlah Perusahaan \\
\hline 1, & $\begin{array}{l}\text { Jumlah sampel perusahaan yang tergabung dalam } \\
\text { Indeks LQ45 periode } 2015-2017\end{array}$ & 35 \\
\hline 2 & $\begin{array}{l}\text { Perusahaan yang tergabung dalam Indeks LQ45 } \\
\text { yang tidak menerbitkan (annual report) berturut- } \\
\text { turut selama periode 2015-2017 }\end{array}$ & (6) \\
\hline 3, & $\begin{array}{l}\text { Perusahaan yang tergabung dalam Indeks LQ45 } \\
\text { Yang tidak mengungkapkan informasi modal } \\
\text { intelektual secara lengkap selama periode 2015- } \\
2017\end{array}$ & (2) \\
\hline 4 & $\begin{array}{l}\text { Perusahaan yang tergabung dalam Indeks LQ45 } \\
\text { yang tidak menyajikan laporan keuangan dengan } \\
\text { mata uang rupiah selama periode } 2015-2017\end{array}$ & (3) \\
\hline & Sampel yang digunakan & 24 \\
\hline & Jumlah Amatan Penelitian (2015-2017) & 72 \\
\hline
\end{tabular}

Sumber: Data Penelitian, 2019

Seperti Tabel 1, selama periode 2015-2017, terdapat keseluruhan 35 perusahaan. Namun, setelah memilih populasi sesuai dengan kriteria yang 
ditetapkan oleh penelitian ini, hanya ditmukan 24 perusahaan yang layak menjadi sampel untuk penelitian.

Tabel 2. Hasil Statistik Deskriptif

\begin{tabular}{lccccc}
\hline & N & Minimum & Maximum & Mean & Std. Deviation \\
\hline Tanggungjawab Sosial & 72 & 0,02 & 0,27 & 0,15 & 0,05 \\
Human Capital & 72 & 1,68 & 12,74 & 4,25 & 2,18 \\
Capital Employed & 72 & 0,06 & 0,94 & 0,25 & 0,18 \\
Structural Capital & 72 & 0,40 & 0,92 & 0,70 & 0,13 \\
Valid N (listwise) & 72 & & & &
\end{tabular}

Sumber: Data Penelitian, 2019

Tabel 2, menunjukan bahwa terdapat 72 data observasi. Pengambilan sampel menunjukan bahwa terdapat 24 perusahaan dengan indeks LQ45 di Bursa Efek Indonesia dari tahun 2015 sampai dengan tahun 2017. Tabel 2, menyatakan bahwa nilai minimum variabel indeks LQ45 Bursa Efek Indonesia dari tahun 2015 sampai dengan 2017 adalah 0,02, yaitu 2 persen diperoleh dari PT. Media Nusantara Citra, Tbk dan nilai maksimum yang diperoleh dari PT adalah 0,27 atau 27 persen. Indofood Sukses Makmur, Tbk. Mean dari variabel ini adalah 0,15, dan standar deviasi adalah 0,05. Standar deviasi skor tanggung jawab sosial lebih rendah dari rata-rata, yang merupakan indikator yang baik karena standar deviasi mencerminkan deviasi data yang rendah atau homogen.

Nilai minimum variabel independent human capital perusahaan indeks LQ45 Bursa Efek Indonesia dari tahun 2015 hingga tahun 2017 adalah 1,68 atau 168 persen yang merupakan nilai HC terendah yang didapat dari PT. Astra International, Tbk dan nilai maksimum diperoleh dari PT 12,74. Indocement Tunggal Prakasa, Tbk. Rerata atau mean dari variabel HC adalah 4,25, dan standar deviasinya adalah 2,18. Dari perolehan ini dapat disimpulkan bahwa nilai rataratanya lebih besar, sehingga hal ini dapat disimpulkan bahwa data deviasi rendah.

Nilai minimum perusahaan yang menggunakan variabel independent capital operation dan indeks LQ45 untuk Bursa Efek Indonesia selama periode 20152017 adalah 0,06 atau 6 persen yang didapat h dari PT. Lippo Karawaci, Tbk, nilai maksimum yang diperoleh dari PT adalah 0,94 atau 94 persen. Matahari Department Store, Tbk. Mean dari variabel CE adalah 0,25, dan standar deviasinya adalah 0,18. Perhitungan tersebut menyatakan bahwa nilai rerata lebih besat, sehingga hal ini dapat disimpulkan bahwa data deviasi rendah atau seragam.

Nilai minimum variabel independen structural capital yang diperoleh dari PT untuk perusahaan dengan indeks LQ45 di Bursa Efek Indonesia selama periode 2015-2017 adalah 0,40 atau 40 persen. Nilai maksimum yang didapat dari Astra International, Tbk dan PT adalah 0,92 atau 92 persen. Indocement Tunggal Orakasa, Tbk. Rerata atau mean dari variabel SC adalah 0,70, dan standar deviasinya adalah 0,13 . Dengan ini dapat disimpulkan bahwa nilai rata-rata lebih besar, sehingga hal ini dapat menunjukkan bahwa data deviasi rendah atau homogen. 
Tabel 3. Hasil Uji Analisis Regresi Linear Berganda

\begin{tabular}{|c|c|c|c|c|c|c|}
\hline \multirow{2}{*}{\multicolumn{2}{|c|}{ Variabel }} & \multicolumn{2}{|c|}{$\begin{array}{l}\text { Unstandardized } \\
\text { Coefficients }\end{array}$} & \multirow{2}{*}{$\begin{array}{c}\begin{array}{c}\text { Standardized } \\
\text { Coefficients }\end{array} \\
\text { Beta }\end{array}$} & \multirow[t]{2}{*}{$\mathrm{t}$} & \multirow[t]{2}{*}{ Sig. } \\
\hline & & B & Std. Error & & & \\
\hline \multirow{2}{*}{\multicolumn{2}{|c|}{$\begin{array}{l}\text { Constant } \\
\text { Human Capital }\end{array}$}} & 0,188 & 0,040 & & 4,725 & 0,000 \\
\hline & & 0,015 & 0,004 & 0.643 & 3,371 & 0,001 \\
\hline \multicolumn{2}{|l|}{ Capital Employed } & $-0,021$ & 0,031 & $-0,073$ & $-0,659$ & 0,512 \\
\hline \multicolumn{2}{|l|}{ Structural Capital } & $-0,139$ & 0,076 & $-0,349$ & $-1,816$ & 0,074 \\
\hline Constant & 0,188 & & & F Hitung & 4,864 & \\
\hline R Square & 0,177 & & & Probabilitas/Sig. & 0,004 & \\
\hline Adj. R Square & 0,140 & & & & & \\
\hline
\end{tabular}

Sumber: Data Penelitian, 2019

Dapat dilihat dari Tabel 3, nilai Adjusted R2 sebesar 0,177 yaitu hanya 17,7 persen variabel yang bisa menjadi pengungkapan tanggung jawab sosial dan dapat dijelaskan oleh variabel human capital, use of capital, dan structural capital, dan selebihnya tidak dapat dijelaskan oleh beberapa variabel yang dijadikan bahan untuk data dalam penelitian ini . Tabel 3, tersebut terlihat nilai F hitung sebesar 4,864 dan nilai signifikansi 0,004. Dan ini membuktikan bahwa model penelitian telah lulus uji kelayakan model.

Uji parsial dilakukan dalam penelitian ini bertujuan dalam memahami apakah ada dampak pada pengungkapan tanggung jawab sosial antara model intelektual perlindungan human capital, capital employed, dan structural capital. Ghozali \& Latan (2015) mengemukakan bahwa standar uji T adalah ketika probabilitas signifikansi tidak mencapai 0,05, hasil perhitungan Analisa data menjelaskan, variable bebas mempunyai pengaruh signifikan terhadap variabel terikat. Hasil analisis yang dilakukan dalam penelitian ini sebagai berikut. Pengaruh human capital terhadap pengungkapan tanggung jawab sosial.

Nilai probabilitas dari human capital adalah 0,001, tidak mencapai nilai signifikansi 0,05 . Artinya, dengan pandangan bahwa variabel lain tetap tidak berubah, sumber daya manusia dalam perhitungan ini dianggap memiliki pengaruh yang cukup kuat terhadap tanggung jawab sosial, sehingga Hipotesis 1 dikatakan berlaku.

Keterampilan dan tingginya kualitas sumber daya manusia adalah keunggulan dari nilai persaingan perusahaan. Penelitian dari Razaindrambinina \& Kariodimejo (2011) mendukung hasil dari penelitian ini dan tidak berselisih dengan teori researh-based yang meyakini bahwa setiap perusahaan memiliki sumber daya yang berbeda dan unik. Sumber daya manusia yang dimanfaatkan dan dikelola dengan baik dapat meningkatkan nilai jual dan nilai tambah bagi perusahaan. Jika produktivitas meningkat maka akan berdampak pada peningkatan pendapatan dan keuntungan perusahaan, sehingga diharapkan berpengaruh bagi perusahaan dalam memenuhi tanggung jawab sosial yang lebih luas. Namun hasil penelitian ini cukup berbeda dengan pernyataan Aulia \& Septiani (2015) dalam penelitianya yang mendukung bahwa variabel HCE memiliki pengaruh yang negatif terhadap tanggung jawab sosial yang artinya jika produktivitas karyawan meningkat maka tidak akan mempengaruhi keuntungan perusahaan. 
Pengaruh capital employed terhadap pengungkapan tanggung jawab sosial. Nilai probabilitas Modal yang terlibat adalah 0,512, tentu saja niai diasumsikan lebih besar dari pada nilai signifikansi yaitu 0,05. Ini dapat tergambar bahwa dengan asumsi variabel lain yang tetap, maka modal yang digunakan berdasarkan perhitungan dianggap tidak memiliki pengaruh yang kuat terhadap tanggung jawab sosial, sehingga Hipotesis 2 tidak dapat diterima.

Perhitungan hasil Analisa menunjukkan bahwa perusahaan yang terindeks LQ45 di Bursa Efek Indonesia selama 2015-2017 tidak berhasil menerapkan aktivitas yang diciptakan oleh modal yang digunakan dalam meningkatkan nilai tambah, dan perusahaan tidak dapat memanfaatkan dana yang tersedia untuk meningkatkan nilai. Selain itu hasil yang didapat dari penelitian ini menunjukkan bahwa lemahnya kerjasama bisnis dengan pelanggan yang menyebabkan turunnya keuntungan perusahaan. Hal ini selaras dengan pernyataan dari Ratnaningrum \& Muhamad (2015) yang menampilkan bahwa tanggung jawab sosial tidak dipengaruhi oleh modal yang digunakan perusahaan. Perhitungan menunjukkan bahwa kontribusi masing-masing elemen PK justru akan mempengaruhi tanggung jawab sosial, sehingga mengurangi nilai tambah. Hasil yang diberikan oleh Razaindrambinina \& Kariodimejo (2011) dan Aulia \& Septiani (2015) berbeda dengan hal tersebut, dimana tampak bahwa modal yang digunakan berdampak pada tanggung jawab sosial. Penelitian ini juga tidak menampilkan kesamaan teori berbasis sumberdaya yang meyakini bahwa semakin tinggi modal intelektual yang dimiliki perusahaan, maka semakin besar pula kemampuan perusahaan untuk memperoleh keunggulan bersaing dan tanggung jawab sosialnya semakin besar.

Pengaruh structural capital terhadap pengungkapan tanggung jawab sosial. Nilai probabilitas structural capital mencapai 0,074, ini lebih besar dari standar nilai signifikansi 0,05. Ini menggambarkan bahwa dengan asumsi disaat variabel lain tetap, tidak berubah, maka modal struktural tidak berpengaruh signifikan terhadap pengungkapan tanggung jawab sosial, sehingga Hipotesis 3 tidak dapat diterima.

Menurut teori ini, penggunaan structural capital yang tepat oleh suatu perusahaan akan memberikan keunggulan kompetitif bagi perusahaan, menciptakan nilai tambah, dan berdampak pada peningkatan kinerja perusahaan. Pertumbuhan kinerja perusahaan akan berdampak pada peningkatan pendapatan perusahaan, sehingga diharapkan pengungkapan tanggung jawab sosial juga dapat meningkat. Namun, perusahaan Indonesia tidak dapat mengelola hak kekayaan intelektualnya, sehingga tidak memiliki kemampuan dalam menghasilkan nilai tambah bagi perusahaan. Oleh karena itu, SC tidak berdampak pada ketidakmampuan perusahaan untuk mengelola dan menggunakan hak kekayaan intelektualnya dan pengungkapan tanggung jawab sosial yang dapat menciptakan nilai tambah bagi perusahaan, yang mengakibatkan kegagalan perusahaan untuk mencapai kondisi terbaiknya. Keuntungan perusahaan. Selain itu, salah satu unsur modal intelektual tidak menjadi pertimbangan dalam pengambilan keputusan saat mengungkapkan tanggung jawab sosial, sehingga perusahaan lebih mampu menciptakan nilai tambah melalui aset berwujud. Hasil penelitian ini seiring dengan hasil penelitian Razaindrambinina \& Kariodimejo 
(2011) dan Aulia \& Septiani (2015) yang mendapatkan bahwa social responsibility tidak dipengaruhi oleh structural capital.

Perhitungan hasil Analisa menunjukan adanya bukti empiris yang memperkuat teori berbasis sumber daya, teori legitimasi, dan teori kelangkaan sumber daya. Hasil penelitian ini bahkan membuktikan bahwa modal intelektual mempengaruhi social responsibilty perusahaan secara positif dan mendukung gagasan teori berbasis sumber daya, teori legitimasi, dan teori kelangkaan sumber daya, yang menunjukkan bahwa sumber daya yang ada pada sebuah perusahaan bersifat unik dan dapat mempertinggi keunggulan kompetitifnya. Teori ini memiliki ciri, yaitu keunggulan ilmu pengetahuan dan ekonomi, yang terakhir lebih mengandalkan aset tidak berwujud, salah satunya adalah human capital, yang dilakukan melalui kegiatan dengan norma perilaku organisasi yang ada. Selama sistem nilai ini konsisten, perusahaan dapat memperlakukannya sebagai legitimasi. Ketika suatu perusahaan dapat menggunakan dan mengelola potensi sumber daya manusianya, maka potensi tersebut akan berdampak positif bagi perusahaan, oleh karen aitu, hal ini dapat meningkatkan pendapatan dan keuntungan perusahaan. Dari hasil penelitian ini diharapkan dapat memberikan kontribusi yang berguna kepada pihak-pihak terkait. Temuan ini menunjukkan bahwa modal manusiawi punya pengaruh yang positif terhadap penggunaan norma organisasi perusahaan untuk secara efektif menggunakan potensi modal manusia untuk mengembangkan atau mengelola karyawan, sehingga meningkatkan keuntungan perusahaan, yang menunjukkan bahwa penelitian tanggung jawab perusahaan meningkat. Investor harus memberikan perhatian khusus pada informasi tentang kapasitas penggunaan modal ketika memberikan pernyataan perusahaan.

\section{SIMPULAN}

Penelitian ini telah berhasil mendapatkan pengaruh antara human capital dengan social responsibility. Hal ini didapatkan melalui pengujian analisis regresi linier berganda. Hasil penelitian menunjukan bahwa human capital berpengaruh secara positif terhadap social responsibility. Hasil tersebut berarti semakin ditingkatkanya kualitas sumber daya manusia, maka semakin baik pula social responsibility suatu perusahaan. Hal ini menunjukkan bahwa perusahaan Indonesia belum berhasil menciptakan nilai tambah dari setiap aktivitas yang diciptakan oleh modal yang digunakan, dan juga mencerminkan citra perusahaan yang tidak dapat memberikan nilai tambah melalui penggunaan modal yang tersedia. Modal struktural tidak memiliki pengaruh dominan terhadap pengungkapan tanggung jawab sosial. Hal ini menunjukkan bahwa perusahaan Indonesia kurang berhasil dalam mengelola dan menggunakan kekayaan intelektual, yaitu modal struktural, dalam menciptakan nilai tambah bagi perusahaan dengan baik.

Selanjutnya penelitian ini memberikan saran agar penelitian selanjutnya bias mempertimbangkan hal seperti, sampel dari penelitian ini dibatasi pada perusahaan yang memiliki indeks LQ45 di Bursa Efek Indonesia. Sehingga diharapkan penelitian selanjutnya menggunakan rentang sampel yang lebih luas atau menggunakan kategori lain, dan menggunakan periode waktu yang lebih luas. Begitu juga penelitian ini hanya mengkaji hubungan antara human capital, used capital, dan structural capital terhadap pengungkapan tanggung jawab sosial. 
Oleh karena itu, penelitian selanjutnya diharapkan dapat menambahkan variabel lain seperti jenis industri, kepemilikan manajemen dan financial leverage. Selain itu enelitian berikutnya yang ingin menggunakan variabel modal intelektual, sebaiknya menggunakan metode pengukuran modal intelektual seperti metode modal intelektual langsung, metodoe kapitalisasi pasar, dan metode scorecart. Pengungkapan terkait tanggung jawab sosial perusahaan juga harus diperbarui bersamaan dengan kondisi masyarakat yang terus berkembang. Saran untuk investor, berharap untuk lebih memahami pentingnya masalah tanggung jawab sosial di masa depan berdasarkan parameter mereka. Hal ini dikarenakan pemenuhan tanggung jawab sosial perusahaan akan berdampak positif terhadap nilai perusahaan.

\section{REFERENSI}

Abilasha, N., \& Tyagi, P. M. (2019). Impact of CSR on Financial Performance of Top 10 Performing CSR Companies in India. IOSR Journal of Economics and Finance, 10(2), 49-55. https:// doi.org/10.9790/5933-1002024955

Adda, G., Azigwe, J. B., \& Awuni, A. R. (2016). Business Ethics And Corporate Social Responsibility For Business Success And Growth. European Journal of Business and Innovation Research, 4(6), 26-42.

Ahmadian, A., \& Khosrowpour, S. (2017). Corporate Social Responsibility: Past, Present, And Success Strategy For The Future. Journal of Service Science (JSS), 10(1), 1-12. https://doi.org/10.19030/jss.v10i1.10063

Apriliawati, F., \& Hartiyanto, W. (2016). Pengungkapan Corporate Social Responsibility (CSR) Sebelum Dan Sesudah Diberlakukannya. Indocompac, 1(40), 178-192.

Aslam, S., Ahmad, M., Amin, S., Usman, M., \& Arif, S. (2018). The impact of corporate governance and intellectual capital on firm's performance and corporate social responsibility disclosure: Evidence from Australian listed companies. Pakistan Journal of Commerce and Social Science, 12(1), 283-308.

Asmawanti, D., \& Wijayanti, I. O. (2017). Intellectual Capital and Corporate Social Responsibility in Banking Industries in Indonesia. Journal of Economics, $\begin{array}{lllll}\text { Business } \mathcal{E} \text { Accountancy 20(2). } & \text { Ventura, }\end{array}$ https://doi.org/10.14414/jebav.v20i2.787

Aulia, H.R. \& Septiani, A. (2015). Analisis Pengaruh Dewan Pengawas Syariah dan Intellectual Capital Terhadap Corporate Social Responsibility Pada Bank Syariah Di Indonesia. Diponogoro Journal Of Accounting, 4(2), 1-9.

Barokah, S. (2018). Pengaruh Intellectual Capital Terhadap Financial Performance ( Studi Pada Perusahaan Sub Sektor Property dan Real Estate yang Terdaftar di Bursa Efek Indonesia ( BEI ) Tahun 2014-2016 ). Jurnal Administrasi Bisnis, 55(1), 132-140.

Bella, L. K. G., \& Suaryana, I. G. . A. (2017). Pengaruh Ios Dan Pengungkapan CSR Pada Nilai Perusahaan Dengan Pertumbuhan Perusahaan Sebagai Variabel Pemoderasi. E-Jurnal Akuntansi Universitas Udayana, 19(1), 508-535. Retrieved from https:/ / ojs.unud.ac.id/index.php/Akuntansi/article/view/27227

Bontis, N., Keow, W. C. C., \& Richardson, S. (2000). Intellectual capital and business performance in Malaysian industries. Journal of Intellectual Capital, 1.

Brennan, N. (2001). Reporting intellectual capital in annual reports: evidence from 
Ireland. Accounting, Auditing \& Accountability Journal.

Edvinsson, L., \& Malone, M. (1997). Intellectual Capital: Realizing Your Company's True Value by Finding Its Hidden Brain-power. Harper Collins.

Gallardo-Vázquez, D., Valdez-Juárez, L. E., \& Lizcano-álvarez, J. L. (2019). Corporate social responsibility and intellectual capital: Sources of competitiveness and legitimacy in organizations' management practices. Sustainability (Switzerland), 11(20), 1-12. https:// doi.org/10.3390/su11205843

Ghozali, I., \& Latan, H. (2015). Partial least squares: Konsep, teknik, dan aplikasi menggunakan program smart PLS 3.0. Universitas Diponegoro.

Hartati, N., \& Idrus, O. (2018). The Determinants of Intellectual Capital in Improving Indonesian Transportation Firms' Performance. 3rd Comparative Asia Africa Governmental Accounting (CAAGA) Conference 2018, 1(1), 18.

Hartono, E. (2018). Implemetasi Pengungkapan Corporate Social Responsibility pada Perusahaan Sektor Industri Dasar dan Kimia. Jurnal Kajian Akuntansi, 2(1), 108. https:// doi.org/10.33603/jka.v2i1.1299

Ikatan Akuntan Indonesia (IAI). (2009). Standar Akuntansi Keuangan revisi. Salemba Empat.

Iwamoto, H., \& Suzuki, H. (2019). An empirical study on the relationship of corporate financial performance and human capital concerning corporate social responsibility: Applying SEM and Bayesian SEM. Cogent Business $\mathcal{E}$ Management, 6(1), 1-20.

Luthan, E., Asniati, \& Yohana, D. (2016). A Correlation of CSR and Intellectual Capital, its Implication toward Company's Value Creation. International Journal of Business and Management Invention, 5(11), 88-94. Retrieved from https://www.ijbmi.org/papers/Vol(5)11/K0511088094.pdf

Marbun, G., \& Saragih, A. E. (2018). Pengaruh Intellectual Capital Terhadap Kinerja Perusahaan Pada Perusahaan Perbankan Yang Terdaftar Di Bursa Efek Indonesia. Jrak, 4(1), 39-60.

Musibah, A. S., \& Sulaiman, W. (2015). The Mediating Effect of Financial Performance on the Relationship between Sharia Supervisory Board Effectiveness, Intellectual Capital and Corporate Social Responsibility, of Islamic Banks in Guf Cooperation Council Countries. Asian Social Science, 10(17), 17.

Nugroho, W. S., \& Gudono, G. (2018). The Significance Key of Intellectual Capital To Increase Financial Performance, Firm's Growth, and Market Value. The Indonesian Journal of Accounting Research, 21(2), 269-290. https:// doi.org/10.33312/ijar.361

Olmedo-Cifuentes, I., \& Martínez-León, I. (2015). Human Capital and Creation of Reputation and Financial Performance. The Electronic Journal of Knowledge Management, 13(3), 209-218.

Parinduri, L., Marlanfar, \& Halim, A. (2019). Penerapan Corporate Social Responsibility. Buletin Utama Teknik, 14(3), 210-214.

Petty, R., \& Guthrie, J. (2000). Intellectual Capital Literature Review: Measurement, Report-ing, and Management. Journal of Intellectual Capital, 1.

Ratnaningrum, \& Muhamad, N. (2015). Peran Intellectual Capital Dalam Memprediksi Pengungkapan Tanggungjawab Sosial Perusahaan. Jurnal Akuntansi Dan Manajemen, 25(2), 1-12. 
Razaindrambinina, \& Kariodimejo, D. (2011). Is company Intellectual capital linked to Corporate Social Responsibility Disclosure? Findings from Indonesia. IBIMA Publishing.

Sagara, Y., \& Chairunissa, C. (2018). The Effect of the Intellectual Capital Measurement, the Corporate Social Responsibility Disclosure and the Firm's Capital Structure on the Financial Performance. KnE Social Sciences, 1(1), 1-12. https://doi.org/10.18502/kss.v3i8.2507

Socoliuc, M., Grosu, V., \& Hlaciuc, E. (2018). Analysis of Social Responsibility and Reporting Methods of Romanian Companies in the Countries of the European $\begin{array}{lll}\text { Union. Sustainability, } & 4662 .\end{array}$ https://doi.org/https://doi.org/10.3390/su10124662

Sukma, H. A. (2018). Perspektif The Resource Based View (Rbv) Dalam Membangun Competitive Advantage. Jurnal Ekonomi Dan Bisnis Islam, 1(1), 709-715. https://doi.org/10.20595/jjbf.19.0_3

Syafrullah, S., \& Muharam, H. (2017). Analisis Pengaruh Kinerja Environmental , Social , Dan Governance ( Esg ) Terhadap Abnormal Return. Ejournal Undip, $6(2), 1-14$

Zahidy, A. A., Sorooshian, S., \& Hamid, Z. A. (2019). Critical success factors for corporate social responsibility adoption in the construction industry in Malaysia. Sustainability (Switzerland), $11(22), \quad 1-24$. https://doi.org/10.3390/su11226411 